\title{
Hydrocarbon Generation Potential of the Campano-Maastrichtian Dark Mudstone Lithofacies, Benin Flank, South West Anambra Basin, Nigeria
}

\author{
*EDEGBAI, AJ; EMOFURIETA, WO
}

\author{
Department of Geology, Faculty of Physical Sciences, University of Benin, Benin-City, Nigeria \\ "Corresponding Author Email: aitalokhai.edegbai@uniben.edu; Tel: +2348137114844
}

\begin{abstract}
The dark mudstone lithofacies of Mamu Formation was deposited during the Campano-Maastrichtian flooding episode. It is laterally heterogeneous, and has been subdivided into marsh, bay and central basin subenvironments in order of proximality. Arising from recommendation from a previous study, we evaluated its hydrocarbon generating potential using multidisciplinary tools involving visual kerogen analysis, as well as bulk and isotope geochemistry. Seventy-seven sample materials were taken from 3-outcrop sites at Uzebba, Okpekpe and Imiegba locations, Benin flank, SW Anambra Basin, Nigeria. The results show that bulk of the samples have good organic richness. Kerogen quality is dominantly of gas prone Type III kerogen. However, visual kerogen analysis indicates the presence of an oil prone Type II/III kerogen in the central basin subenvironments. An immature thermal maturity is inferred based on spore colour index (SCI) of less than 6 on the SCI chart (thermal alteration index of $<2.5$ ). In addition, we hypothesize that the dark mudstone lithofacies possesses biogenic gas potential based on its organic richness, kerogen quality and thermal maturity. Shale gas prospectivity is further enhanced by the low dip of the Mamu Formation, shallow burial as well as high silica content. Worth mentioning is the proximal marsh mudstone (Uzebba location) with suitable microfabric, very high silica as well as $>10 \mathrm{~m}$ of combined (continuous) outcropping and subcropping thickness.
\end{abstract}

\section{DOI: https://dx.doi.org/10.4314/jasem.v24i11.8}

Copyright: Copyright $(0) 2020$ Edegbai and Emofurieta. This is an open access article distributed under the Creative Commons Attribution License (CCL), which permits unrestricted use, distribution, and reproduction in any medium, provided the original work is properly cited.

Dates: Received: 20 September 2020; Revised: 29 October 2020; Accepted: 10 November 2020

Keywords: Kerogen, palynofacies, stable isotope geochemistry, shale gas,

Visual kerogen analysis complemented by bulk and isotope geochemistry have proven to be very useful tools in evaluating the hydrocarbon generation potential of fine-grained lithologic units (Tyson, 1995; Al-Ameri et al., 1999; Chiaghanam, et al., 2013; Gonçalves et al., 2015). A clear advantage of visual kerogen analysis over other tools is that it provides valuable information on the nature of the particulate organic matter that constitute the kerogen, their characteristics, as well as the proportion of various organic matter constituents (Tyson, 1995). In addition, it is simple, relatively inexpensive yet very powerful (Thakur and Dogra, 2011; Mendonça Filho et al., 2012). Renewed interest in hydrocarbon exploration of Nigeria's inland basins (especially the Benue Trough, Benin and the Anambra basins) in recent times have provided a strong impetus for a good understanding of its petroleum system elements. At the core of this is the understanding of the basins' Cretaceous source rocks. The source rock properties of the mudstone (shale) and coal of Campano-Maastrichtian Mamu Formation, Anambra Basin have been evaluated mostly in the eastern segment using programmed pyrolysis (Akaegbobi et al., 2000; Ogala 2011; Akande et al., 2012; Olatinpo et al., 2016; Faboya et al., 2019), whereas only a few studies exist in the southwestern segment (Edegbai and Emofurieta, 2015; Ogbamikhumi et al., 2017 Maju-Oyovwikowhe and Malomi, 2019). Data from these findings have been used to characterize the Mamu Formation as having well to very good organic richness with thermally immature to early mature dominantly type III kerogen. Interestingly, some of the data suggest the occurrence of marine and mixed marine kerogen (Olatinpo et al., 2016; Faboya et al., 2019), which is attractive to petroleum explorers. Hence, the need for kerogen / organic facies analysis to be undertaken on the dark mudstone. In our preliminary assessment of the source potential of the dark mudstone lithofacies of the Mamu Formation in the Benin flank of the Anambra Basin (Edegbai and Emofurieta, 2015), we recommended a detailed study of the dark mudstone unit. Following through with this, detailed studies with aimed at unraveling the prevalent paleodepositional and paleoceanographic conditions of the Maastrichtian seaway (Edegbai et al., 2019a, 2019b, 2020) was undertaken. This present effort embodies the findings of a detailed multidisciplinary evaluation (palynofacies, bulk geochemistry and carbon isotope geochemistry) of the dark mudstone lithofacies aimed at assessing the source rock potential of the dark mudstone unit outcropping at Uzebba, Okpekpe 
Imiegba locations, Benin Flank, western Anambra Basin, as well as its implication for shale gas development.

Geologic Setting: The Anambra Basin (Fig. 1) marks the next to last stage of the Benue Trough's tectonostratigraphic evolution in Southern Nigeria (Edegbai et al., 2019a). It is generally believed to be a continental sag basin formed after thermal induced subsidence which followed the widespread Santonian inversion episode. However, recent schools of thought suggest an interior fracture basin (Ladipo pers. Comm., 2019) or a faulted passive margin (Omatsola, 2019). The wedge-shaped outline of the lithic fill, the presence of synsedimentary deformation structures (Obi and Okogbue, 2004) as well field evidences of normal faults (Dim et al., 2020) are evidences for fault-controlled subsidence. The Anambra Basin has a Campanian to Danian stratigraphic fill which is composed of the Nkporo Group, the Mamu Formation, the Ajali Formation and the Nsukka Formation in stratigraphic order (Fig. 1, Table 1). Lithostratigraphy of the Mamu Formation in the Benin Flank: The Mamu Formation in the Benin flank comprises of 7lithofacies, which were combined into marsh, bay, barrier, beach, and washover fan lithofacies association as well as meandering fluvial-tidal channel lithofacies association Edegbai et al (2019b). Dark mudstone lithofacies: The dark mudstone is one of the 7-lithofacies identified in the western flank. At the Imiegba and Uzebba outcrops (Fig. 3), thicknesses of up to $6 \mathrm{~m}$ exist. Texturally, it shows poor sorting and varies from fine mudstone to sandy mudstone with fabric characterized by laminations, which may be planar, lenticular, wavy, or curved. It is weakly to moderately bioturbated, which is a function of proximality and water depth (Edegbai, et al., 2019b). Mineralogically, it is devoid of calcite, and has a composition that varies between $100 \%$ quartz and clay (mainly kaolinite) (Edegbai, et al., 2019b). In addition, geochemical microfabric, paleontological characterization show that the dark mudstone is laterally heterogeneous, which led to the identification of 3-subenvironments: marsh, bay and central basin (Edegbai, et al., 2019b) in order of proximality.

\section{MATERIALS AND METHODS}

Kerogen analysis: Kerogen slides were prepared for 74 (7 composite) samples (Fig. 2) following standard procedures (Traverse, 2007). Subsequently thereafter, palynofacies characterization, which involved identification of the kerogen constituents, grouping of palynological organic matter (using a simple scheme that comprises of aquatic amorphous organic matter, phytoclast, and palynomorph) and point counting a minimum of 300 constituents before normalizing to $100 \%$.
Total organic carbon, Total nitrogen, and stable organic carbon isotope measurements: Seventy-four samples were analyzed for total organic carbon (TOC), and total nitrogen $\left(\mathrm{N}_{\mathrm{t}}\right)$ at the Stable Isotope Mass Spectrometry Laboratory, University of Florida (UF), USA, as well as at the Organic and Isotope Geochemistry Departmental Laboratory at Kiel University (CAU), Germany (Fig 3). For quality assurance a few samples were measured in both laboratories to check for data consistency (see Table $2)$. In addition, 50 samples were selected for stable organic carbon isotope $\left(\delta^{13} \mathrm{C}_{\text {org }}\right)$ measurements at UF (Table 2). The experimental procedures employed both laboratories are detailed in Edegbai et al. (2020).

\section{RESULTS AND DISCUSSION}

A summary of the results of palynofacies and geochemical analyses is presented in Table 3.

Organic richness: The TOC vary from 0.24 to $2.96 \%$, with the mean TOC for the central basin, bay and marsh sub-environments are $1.09 \%, 1.39 \%$ and 1.21 $\%$, respectively ( $n=27,23$, and 27 , respectively). The organic richness is more variable in the bay subenvironment $(\mathrm{SD}=0.91 \%)$, than in the marsh $(\mathrm{SD}=$ $0.34 \%$ ) and central basin sub-environment ( $\mathrm{SD}=$ $0.27 \%$ ), which is a reflection of the interplay of productivity and preservation consequent upon relative sea level fluctuations. The organic richness of the samples varies from poor to very good (Peters and Cassa, 1994). On the average, all samples from three sub-environments have good organic richness, whereas only $11 \%$ of all the samples possess very good organic richness (predominantly in the bay subenvironment). The TOC reported is commonplace with realms where significant clastic dilution is prevalent (Tyson, 1995).

Kerogen Quality: The phytoclast group is the most dominant organic matter group with relative abundances varying from $37.22 \%$ to $100 \%$ (Table 3 ). The mean phytoclast proportion for the central basin, bay and marsh sub-environments are $60.86 \%(\mathrm{n}=21$; $\mathrm{SD}=14.95), 93.42 \%(\mathrm{n}=22 ; \mathrm{SD}=6.88)$ and $88.59 \%$ $(\mathrm{n}=27 ; \mathrm{SD}=4.94)$, respectively. The mean palynomorph relative abundances for the central basin, bay and marsh sub-environments are $34.29 \%(\mathrm{n}=21$; $\mathrm{SD}=16.20), 6.27 \%(\mathrm{n}=22 ; \mathrm{SD}=6.77)$ and $10.13 \%(\mathrm{n}$ $=27 ; \mathrm{SD}=4.81)$, respectively. Finally, the mean aquatic amorphous organic matter percentages for the central basin, bay and marsh sub-environments are $4.85 \%(n=21 ; S D=4.60), 0.08 \%(n=22 ; S D=0.19)$ and $1.28 \%(\mathrm{n}=27 ; \mathrm{SD}=0.95)$, respectively. There is lateral variability in relative abundance of particulate organic matter, with the central basin recording the greatest variability. The $\mathrm{Nt}$ values are very low, ranging from 0.03 (at low TOC) to $0.1 \%$ (Table 2). 


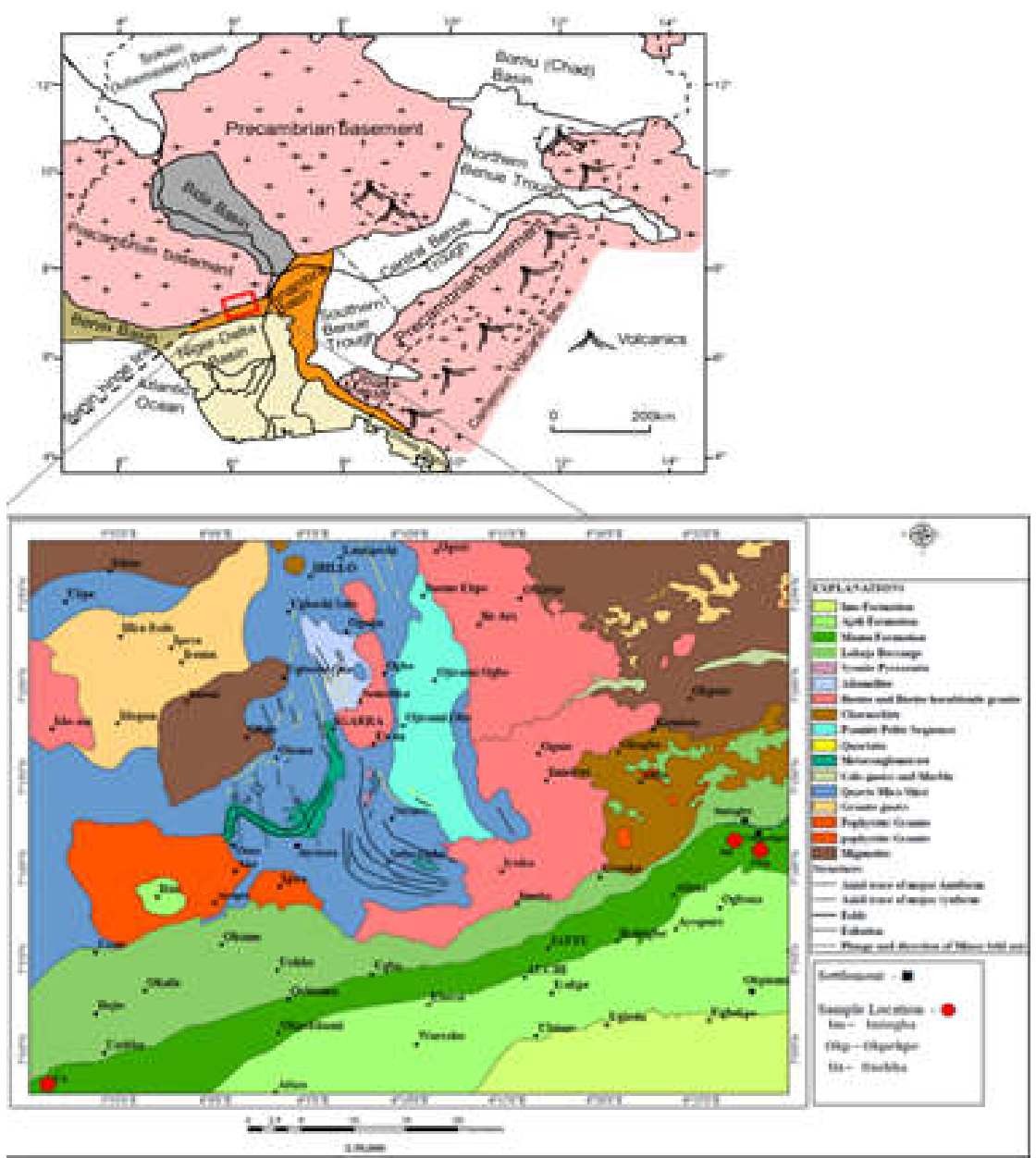

Fig. 1. Geological map of the Benin Flank with sample (outcrop) locations (modified from NGSA, 2006)

Table 1. Summary of Late Cretaceous to Paleocene stratigraphy of Nigerian basins

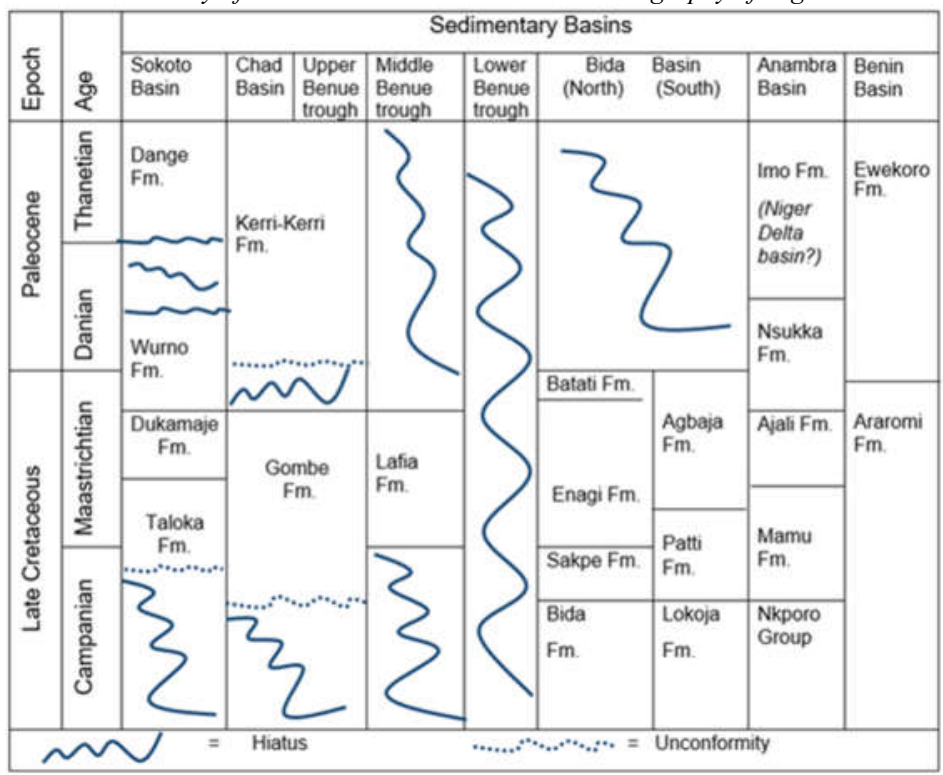

The mean $\mathrm{Nt}$ for the central basin, bay and marsh subenvironments are $0.06 \%(\mathrm{n}=26 ; \mathrm{SD}=0.02), 0.07 \%$ $(\mathrm{n}=23 ; \mathrm{SD}=0.02)$ and $0.06 \%(\mathrm{n}=24 ; \mathrm{SD}=0.01)$, respectively. The central basin, bay and marsh sub- 
environment have mean $\mathrm{TOC} / \mathrm{Nt}$ values of 18.44 , 19.06 and 21.04, respectively (Table 2). The variability around mean $\mathrm{TOC} / \mathrm{Nt}$ values is greatest in the marsh and bay sub-environments $(\mathrm{SD}=9.59$ and 7.60 respectively) and lowest in the central basin subenvironment $(\mathrm{SD}=6.22)$. The $\delta^{13} \mathrm{Corg}$ values of the samples vary in the range of $-23.850 / 00$ (central basin mudstone) to $-27.870 / 00$ (bay mudstone) (Table 3). Mean $\delta^{13}$ Corg are $-25.750 / 00(n=15, S D=0.61)$, $25.970 / 00(\mathrm{n}=16, \mathrm{SD}=0.95)$ and $-26.48(\mathrm{n}=19, \mathrm{SD}$ $=0.24$ ) for the central basin, bay and marsh mudstones, respectively.
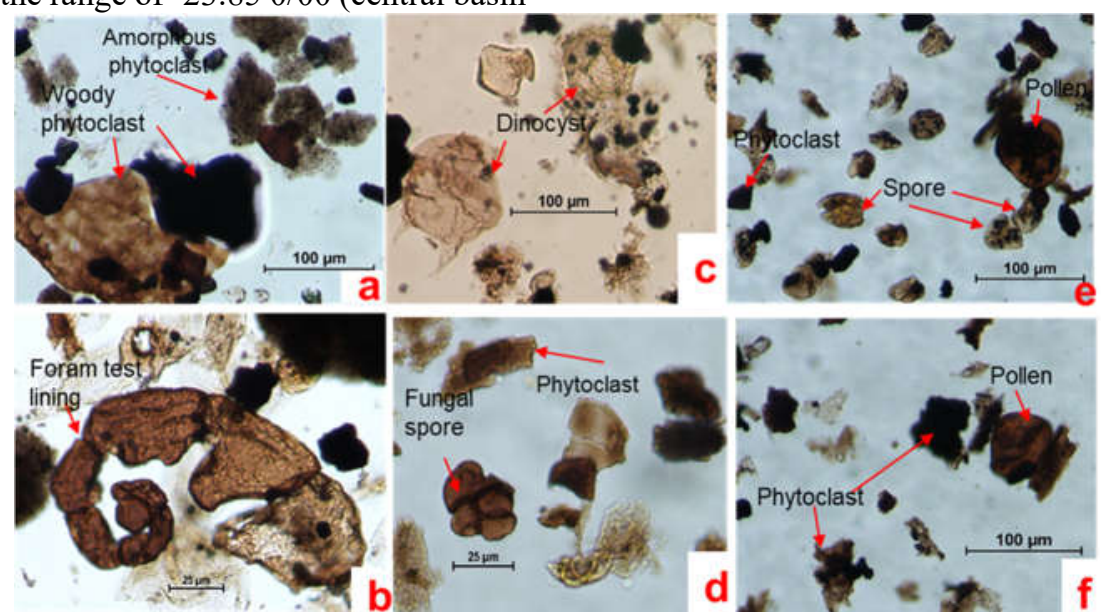

Fig. 2. Photomicrographs showing various types of dispersed organic matter identified (Edegbai et al., 2019b)

Visual kerogen analysis by means of the relative percentages of aquatic amorphous organic matter, phytoclasts and palynomorphs (APP) reveal two palynofacies groups: PF-A and PF-B. The PF-A is defined by a high proportion of phytoclasts predominating over the other organic matter groups, whereas PF-B, is defined by moderate relative

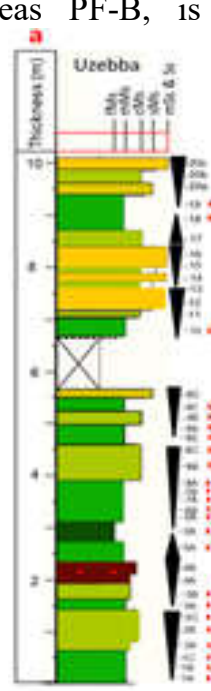

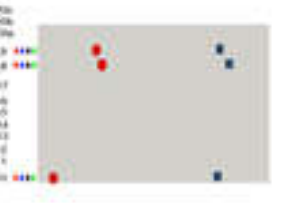
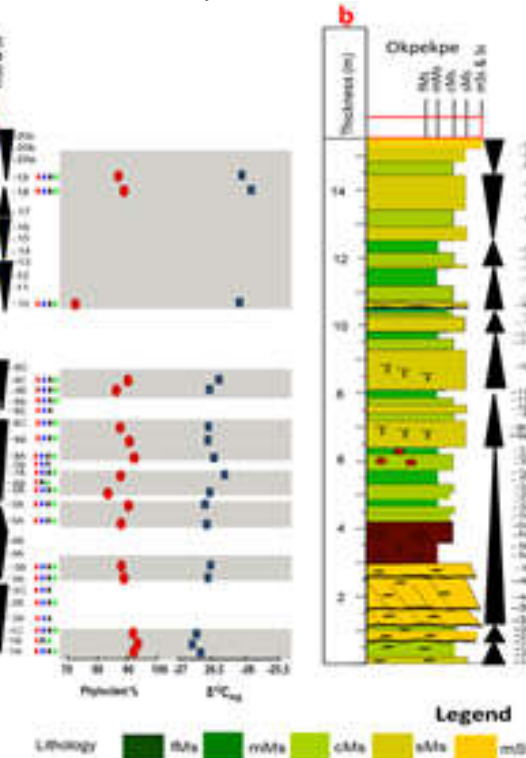

abundance of phytoclasts, and palynomorphs, as well as a low percentage of aquatic amorphous organic matter (Figs. 4-5). We deduct that the PF-A group is congruent with the organic facies $\mathrm{C}$ and $\mathrm{CD}$ (Jones in Tyson, 1995) with gas prone type III kerogen, which is unique to regions proximal to fluvial sources (marsh and bay) (Gonçalves et al., 2015).

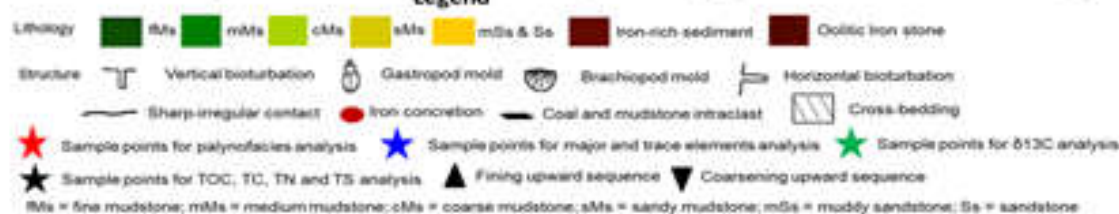

Fig. 3. Graphic logs of the measured sections with sample points. Note the heavier $\delta^{13} C_{\text {org }}$ values corresponding with high phytoclast abundance (adapted from Edegbai et al., 2020). 
Table 2. Raw data used for quality checks

\begin{tabular}{|c|c|c|c|c|c|}
\hline 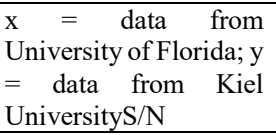 & $\begin{array}{l}\mathrm{N}_{\mathrm{t}} \\
\text { (wt. \%) }\end{array}$ & $\begin{array}{l}\text { TOC } \\
\text { (wt. \%) }\end{array}$ & $\mathrm{S} / \mathrm{N}$ & $\begin{array}{l}\mathrm{N}_{\mathrm{t}} \\
\text { (wt. \%) }\end{array}$ & $\begin{array}{l}\text { TOC } \\
\text { (wt. \%) }\end{array}$ \\
\hline U1-5B (x) & 0.07 & 1.27 & $\operatorname{Im}-2 \mathrm{E}(\mathrm{x})$ & 0.06 & 1.09 \\
\hline (y) & 0.08 & 1.14 & (y) & 0.04 & 0.45 \\
\hline Mean & 0.08 & 1.21 & Mean & 0.05 & 0.77 \\
\hline$S D$ & 0.01 & 0.09 & $S D$ & 0.01 & 0.45 \\
\hline U1-6B (x) & 0.07 & 1.04 & IM 2B (x) & 0.06 & 1.09 \\
\hline (y) & 0.08 & 1.29 & (y) & - & 0.92 \\
\hline Mean & 0.08 & 1.17 & Mean & & 1.01 \\
\hline$S D$ & 0.01 & 0.18 & $S D$ & & 0.12 \\
\hline U1-8B (x) & 0.07 & 1.24 & OK 7E (x) & 0.08 & 2.82 \\
\hline (y) & 0.06 & 1.15 & (y) & 0.11 & 3.10 \\
\hline Mean & 0.07 & 1.20 & Mean & 0.10 & 2.96 \\
\hline$S D$ & 0.01 & 0.06 & $S D$ & 0.02 & 0.20 \\
\hline U1-10 (x) & 0.07 & 2.12 & OK 11B (x) & 0.05 & 0.42 \\
\hline (y) & 0.04 & 2.56 & (y) & - & 0.43 \\
\hline Mean & 0.06 & 2.34 & Mean & & 0.43 \\
\hline$S D$ & 0.02 & 0.31 & $S D$ & & 0.01 \\
\hline
\end{tabular}

Whereas, PF-B group is congruent with the organic facies BC and C (Jones in Tyson, 1995) with gas and oil prone type II/III kerogen, which is characteristic of realms remote from fluvial sources (central basin subenvironment). In addition, clastic dilution is supported

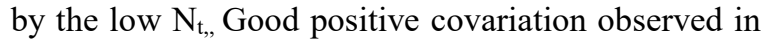
the TOC $v s . \mathrm{N}_{\mathrm{t}}$ binary plot, as well as the clustering of bulk of the data around the TOC/ $\mathrm{N}_{\mathrm{t}} \geq 20$ line, which indicate the dominance of land derived biomass (Meyers, 1994) (Fig 6). In Cretaceous strata it has been shown that there is an enrichment of $\delta^{13} \mathrm{C}_{\text {org }}$ in land derived biomass over marine biomass, which is attributable to C-isotopic fractionation (Arthur et al., 1985). $\delta^{13} \mathrm{C}_{\text {org }}$ data ranges of -29 to -27 and -25 to -24 have been reported for marine and land derived biomass respectively (Arthur et al., 1985). The $\delta^{13} \mathrm{C}_{\text {org }}$ data (Table 3) show the dominance of terrestrial biomass, which is congruent with the findings of Faboya et al (2019) on the eastern segment, as well as bulk geochemistry, palynofacies data as well as hydrogen index data generated in preliminary studies (Edegbai and Emofurieta, 2015).

Table 3A. Summary of data from palynofacies and geochemical analyses (composite samples are indicated with thick borders)

\begin{tabular}{|c|c|c|c|c|c|c|c|c|c|c|}
\hline \multirow{2}{*}{$\begin{array}{c}\text { Sample } \\
\text { No. }\end{array}$} & \multicolumn{2}{|c|}{ Lithofacies } & \multicolumn{3}{|c|}{ Palynofacies data (\%) } & \multicolumn{5}{|c|}{ Geochemistry data } \\
\hline & & & 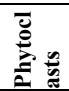 & 产 & AOM & TOC & Nt & 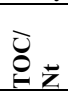 & $\begin{array}{l}\delta^{13} \mathbf{C}_{\text {org }} \\
\text { (permil, } \\
\text { VPDB) }\end{array}$ & vs \\
\hline U1 IA & L1 & Marsh & 92.31 & 5.71 & 1.99 & 1.35 & 0.06 & 22.5 & -26.69 & \\
\hline U1 1B & & & 92.74 & 6.05 & 1.21 & 1.33 & 0.06 & 22.17 & -26.79 & \\
\hline U1 $1 \mathrm{C}$ & & & 91.22 & 7.43 & 1.35 & 1.19 & 0.05 & 23.8 & -26.71 & \\
\hline U1 2A & & & 83.66 & 15.18 & 1.17 & 1.22 & 0.07 & 18.27 & - & \\
\hline U1 2B & & & 86.11 & 13.54 & 0.35 & 0.99 & 0.05 & 19.8 & -26.73 & \\
\hline $\mathrm{U} 12 \mathrm{C}$ & & & 82.49 & 16.50 & 1.01 & 1.17 & 0.06 & 18.90 & - & \\
\hline U1 3A & & & 88.93 & 10.42 & 0.65 & 1.24 & 0.06 & 20.67 & -26.53 & \\
\hline U1 3B & & & 88.20 & 11.15 & 0.66 & 1.2 & 0.06 & 20 & -26.51 & \\
\hline U1 5A & & & 88.49 & 10.20 & 1.32 & 1.78 & 0.08 & 22.25 & -26.56 & \\
\hline U1 5B & & & 90.29 & 9.06 & 0.65 & 1.20 & 0.07 & 16.20 & -26.59 & \\
\hline U1 6A & & & 83.62 & 15.87 & 0.48 & 1.09 & 0.06 & 18.17 & -26.54 & \\
\hline U1 6B & & & 83.62 & 15.87 & 0.48 & 1.04 & 0.08 & 13.59 & -26.46 & \\
\hline U1 7A & & & 87.83 & 9.54 & 2.63 & 1.12 & 0.06 & 18.67 & -26.32 & \\
\hline U1 7B & & & 87.83 & 9.54 & 2.63 & 1.03 & 0.06 & 18.29 & - & \\
\hline $\mathrm{U} 18 \mathrm{~A}$ & & & 92.05 & 5.96 & 1.99 & 1.16 & 0.06 & 19.33 & -26.49 & \\
\hline U1 8B & & & 90.61 & 8.74 & 0.65 & 1.20 & 0.06 & 19.05 & -26.67 & \\
\hline U1 $8 \mathrm{C}$ & & & 90.61 & 8.74 & 0.65 & 0.97 & 0.05 & 19.4 & -26.57 & \\
\hline U1 8D & & & 89.91 & 8.83 & 1.26 & 1.07 & 0.06 & 17.68 & - & \\
\hline U1 9A & & & 89.91 & 8.83 & 1.26 & 1.2 & 0.06 & 20 & -26.55 & \\
\hline U1 9B & & & 86.58 & 11.82 & 1.60 & 1.09 & 0.06 & 18.17 & -26.52 & \\
\hline $\mathrm{U} 19 \mathrm{C}$ & & & 90.23 & 7.82 & 1.95 & 0.8 & 0.06 & 13.33 & -26.39 & \\
\hline U1 10 & & & 72.36 & 25.47 & 2.17 & 2.55 & 0.04 & 64.58 & -26.08 & \\
\hline U1 18 & & & 89.61 & 7.47 & 2.92 & 0.98 & 0.05 & 19.6 & -25.89 & \\
\hline U1 19 & & & 87.54 & 8.85 & 3.61 & 1.23 & 0.06 & 20.5 & -26.05 & \\
\hline
\end{tabular}


In addition, an increase in the proportion of phytoclast is directly proportional to enrichment of $\delta^{13} \mathrm{C}_{\text {org }}$ (Fig. 3 ), which underscores the influence of relative sea level flux and organic facies development.

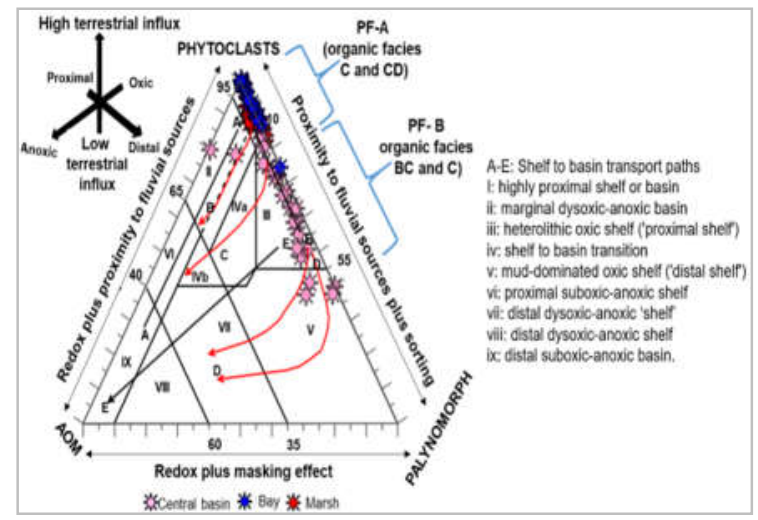

Fig. 4. APP plot showing different palynofacies groups (Edegbai et al., 2020)

Thermal maturity: Maturity assessment based on spore colour index chart was employed. Our findings show that the colour of the spores recovered from all 3 -subenvironments is less than 6.0 on the SCI chart (Pearson, 1984). This is equivalent to a thermal alteration index (TAI) of $<2.5$, indicating a thermally immature kerogen. This concurs with thermal maturity estimates from SCI and Tmax data obtained from our preliminary studies (Edegbai and Emofurieta, 2015), as well as from other studies (Olatinpo et al., 2016; Ogbamikhumi et al., 2017, Maju-Oyovwikowhe and Malomi, 2019; Faboya et al., 2019).

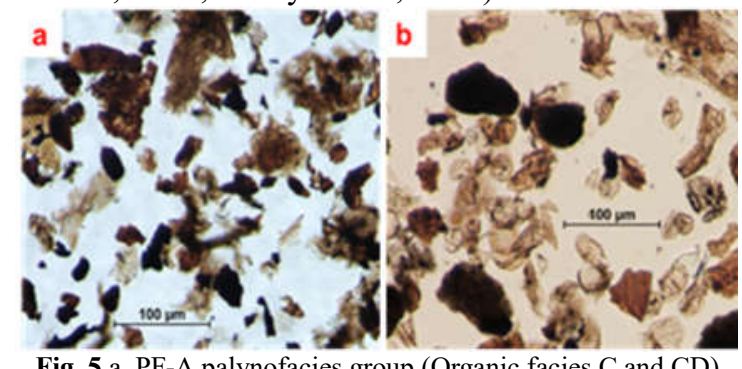

Fig. 5.a, PF-A palynofacies group (Organic facies $\mathrm{C}$ and $\mathrm{CD}$ ) characteristic of the marsh and bay sub-environments. $\mathrm{b}, \mathrm{PF}-\mathrm{B}$ group (organic facies $\mathrm{BC}$ and $\mathrm{C}$ ) characteristic of the central basin sub-environment

Shale gas potential: Following guidelines for geological characterization of shale gas plays (Bouhlel et al., 2012), we can assess the shale gas potential of the dark mudstone lithofacies. The organic richness, which is mostly $<2$ wt. $\%$ fall short of $2 \mathrm{wt} . \%$ which is the preferred minimum for shale gas plays (Troudi et al., 2012). Based on insight from kerogen quality and thermal maturity assessment observed in this study, we infer a biogenic gas potential for the dark mudstone lihofacies. In addition, the gentle dip and shallow burial as well as the silica content $>30 \%$ of large proportion of the dark mudstone lithofacies (especially the marsh sub environment) are desirable attributes for shale plays (Burns et al., 2012).

Table 3B. Summary of data from palynofacies and geochemical analyses (composite samples are indicated with thick borders)

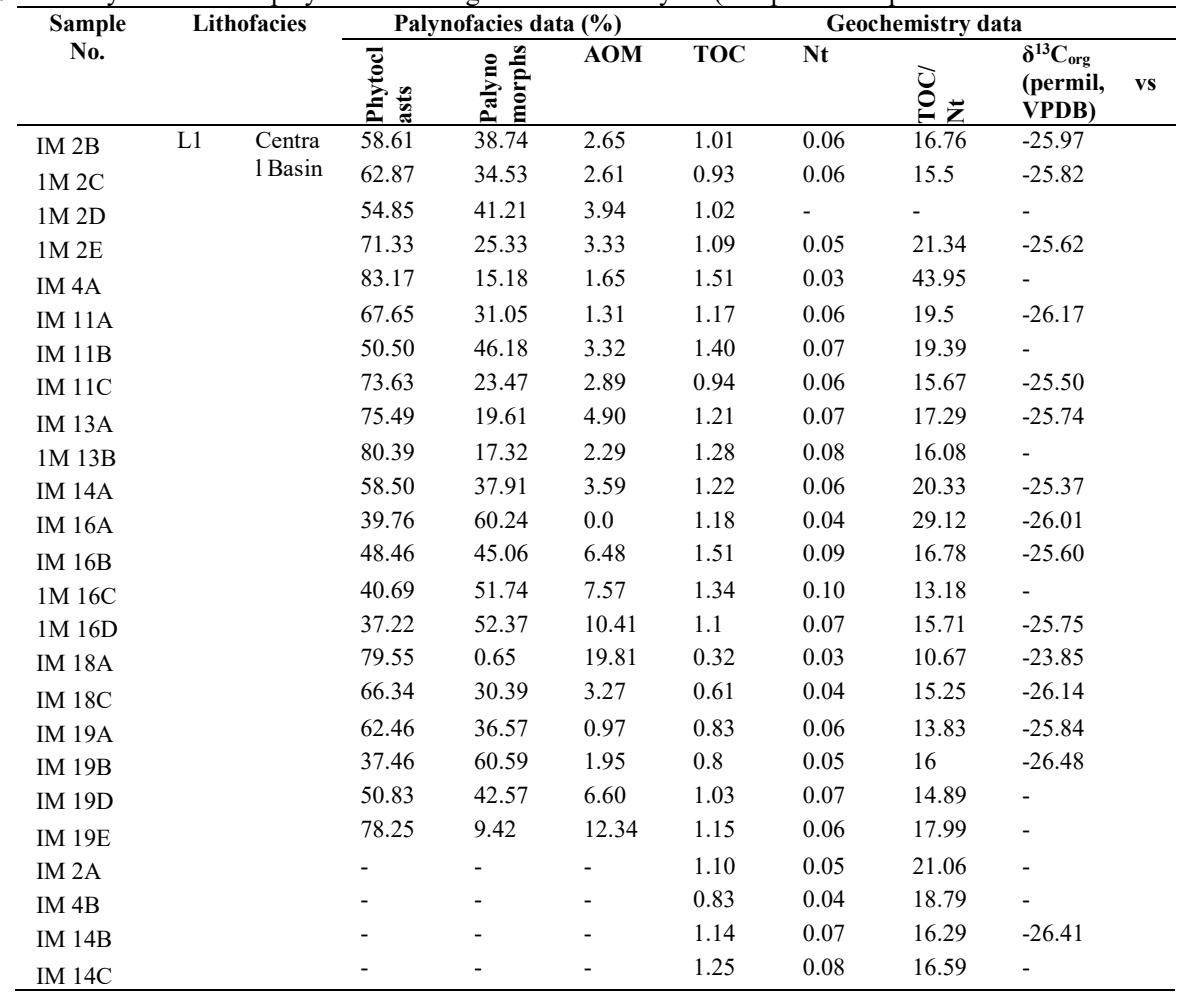




\begin{tabular}{|c|c|c|c|c|c|c|c|c|c|}
\hline IM 18B & & & - & - & - & 1.10 & 0.06 & 18.87 & - \\
\hline IM 19C & & & - & - & - & 1.40 & 0.07 & 18.82 & - \\
\hline OK 7A & $\mathrm{L} 1$ & Bay & 90.72 & 9.28 & 0.0 & 2.52 & 0.09 & 28.0 & -27.59 \\
\hline OK 7B & & & 90.72 & 9.28 & 0.0 & 0.95 & 0.06 & 16.58 & - \\
\hline OK 7C & & & 90.86 & 6.58 & 0.0 & 2.35 & 0.09 & 26.11 & -27.87 \\
\hline OK 7D & & & 90.86 & 6.58 & 0.0 & 2.86 & 0.12 & 24.02 & - \\
\hline OK 7E & & & 71.38 & 28.44 & 0.19 & 2.96 & 0.10 & 30.90 & -27.14 \\
\hline OK 7F & & & 85.11 & 14.89 & 0.0 & 2.19 & 0.09 & 25.26 & - \\
\hline OK 7G & & & 88.34 & 11.66 & 0.0 & 2.48 & 0.09 & 27.56 & -26.77 \\
\hline OK 7H & & & - & - & - & 2.59 & 0.09 & 28.78 & -26.35 \\
\hline OK 7I & & & 88.40 & 11.11 & 0.49 & 1.78 & 0.07 & 24.51 & - \\
\hline OK 7J & & & 88.40 & 11.11 & 0.49 & 1.82 & 0.07 & 26.0 & -25.92 \\
\hline OK 9 & & & 96.79 & 3.21 & 0.0 & 0.24 & 0.05 & 4.76 & - \\
\hline OK $11 \mathrm{~A}$ & & & 99.39 & 0.61 & 0.0 & 0.70 & 0.07 & 9.72 & - \\
\hline OK 11B & & & 99.77 & 0.23 & 0.0 & 0.42 & 0.05 & 8.50 & -24.73 \\
\hline OK $13 \mathrm{~A}$ & & & 98.86 & 1.14 & 0.0 & 0.92 & 0.05 & 17.32 & -25.57 \\
\hline OK 13B & & & 98.66 & 1.34 & 0.0 & 1.30 & 0.08 & 15.85 & - \\
\hline OK 15 & & & 98.79 & 1.21 & 0.0 & 0.38 & 0.03 & 12.67 & -25.47 \\
\hline OK 17 & & & 91.56 & 8.44 & 0.0 & 1.04 & 0.06 & 17.33 & -25.51 \\
\hline OK 19A & & & 99.36 & 0.64 & 0.0 & 1.16 & 0.06 & 19.33 & -25.65 \\
\hline OK 19B & & & 100.0 & 0.0 & 0.0 & 0.68 & 0.05 & 13.60 & -25.17 \\
\hline OK $21 \mathrm{~A}$ & & & 93.79 & 6.21 & 0.0 & 0.27 & 0.03 & 9.0 & -24.95 \\
\hline OK 21B & & & 100.0 & 0.0 & 0.0 & 0.40 & 0.04 & 10.0 & -25.01 \\
\hline OK $24 \mathrm{~A}$ & & & 94.12 & 5.29 & 0.59 & 1.37 & 0.06 & 22.83 & -26.26 \\
\hline OK 24B & & & 99.35 & 0.65 & 0.0 & 0.59 & 0.03 & 19.67 & -25.48 \\
\hline
\end{tabular}

Furthermore, due to its proximity to provenance and shallow depth the microfabric and degree of bioturbation (Edegbai et al., 2020), the marsh subenvironment possesses better petrophysical properties in comparison to the bay and central basin subenvironments. In terms of thickness, the Uzebba and Imiegba locations (marsh and central basin subenvironments) have up to $6 \mathrm{~m}$ of (continuous) outcropping thicknesses of the dark mudstone unit. We estimate the thickness at the Uzebba location to be up to $15 \mathrm{~m}$ inclusive of the subcrop thickness.
Conclusion: This multidisciplinary study has shown that the dark mudstone unit possess good organic richness, whose variability is affected by proximality to provenance as well as relative sea level changes. The dark mudstone unit possess thermally immature kerogen, whose quality is predominantly of gas prone Type III. Nonetheless, visual kerogen analysis indicates the presence of Type II/III kerogen with oil generation potential in the distal central basin subenvironment. The outcropping dark mudstone unit have potential for biogenic gas.

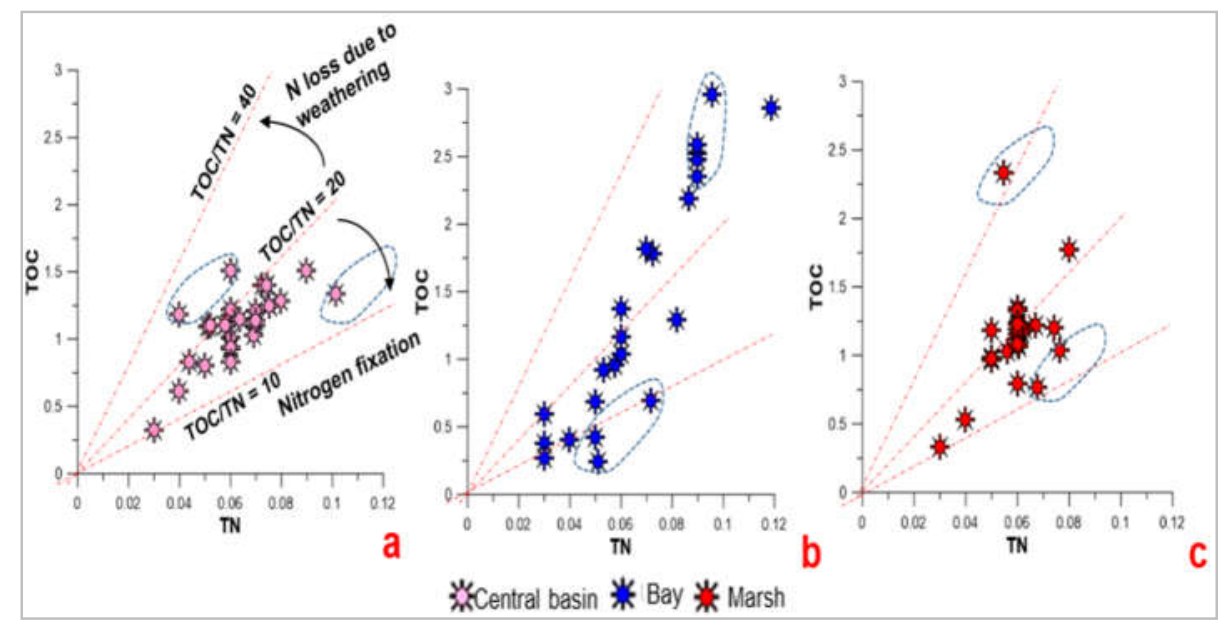

Fig. 6. TOC vs. Nt binary plots for dark mudstone subenvironments (adapted from Edegbai et al., 2020) 


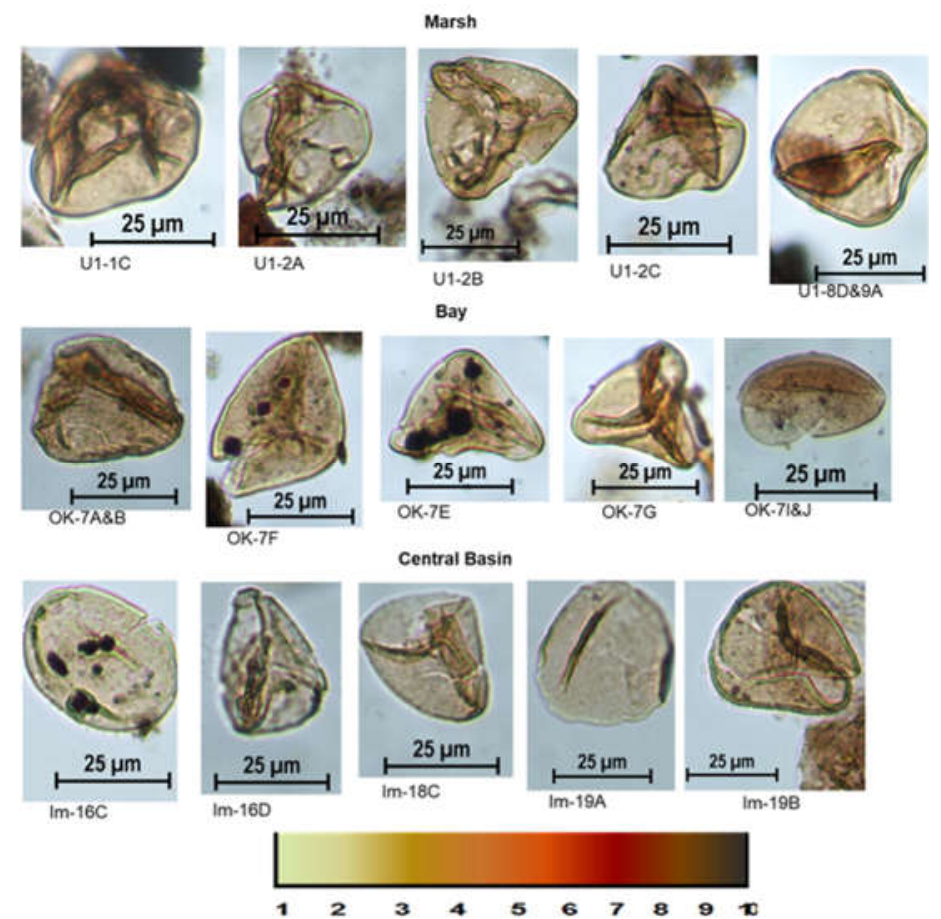

Fig. 7. Spores recovered from the dark mudstone samples. Spore colour index chart adapted from Pearson (1984)

\section{REFERENCES}

Akaegbobi, M. I., Nwachukwu, J. I., and Smith, M (2000). Aromatic hydrocarbon distribution and calculation of oil and gas volumes in Post Santonian Shale and Coal, Anambra Basin, Nigeria. In: Mello, M. R., and Katz, B. J., (eds), Petroleum Systems of South Atlantic Margins. AAPG Memoir 73. p. $233-245$

Akande, S.O., Egenhoff, S.O., Obaje, N.G., Ojo, O.J., Adekeye, O.A., Erdtmann, B.D (2012). Hydrocarbon potential of Cretaceous sediments in the Lower and Middle Benue Trough, Nigeria: Insights from new source rock facies evaluation. J. Afr. Earth Sci 64:34-47

Al-Ameri, T.K., Al-Musawi, F.S., and Batten, D.J (1999). Palynofacies indications of depositional environments and source potential for hydrocarbons: uppermost Jurassic-basal Cretaceous Sulaiy Formation, southern Iraq. Cretaceous Res. 20: 359-363

Arthur, M.A., Dean, W.E., Claypool, G.E (1985). Anomalous 13C-enrichment in modern marine organic matter. Nature 315:216-218

Bouhlel, A.M., Bryant, I (2012). An effective Approach to Unconventional Resource Exploration in the Middle East, Paper SPE 152455, presented at the SPE Middle East
Unconventional Gas Conference and Exhibition, Abu Dhabi, UAE 23-25 January

Burns, C., Topham, A., Lakani, R (2012). The Challenges of Shale Gas Exploration and Appraisal in Europe and North Africa, Paper SPE 151868, presented at the SPE/EAGE European Unconventional Resources Conference and Exhibition, Vienna, Austria 20-22 March

Chiaghanam, O.I., Chiadikobi, K.C., Ikegwuonu, O.N., Omoboriowo, A.O., Onyemesili, O.C., Acra E.J (2013). Palynofacies and Kerogen Analysis of Upper Cretaceous (Early Campanian to Maastrichtian) Enugu Shale and Mamu Formation in Anambra Basin, South-Eastern Nigeria: Inter. J. Sci. Tech. Res. 2(8): 87-97

Dim, C.I.P., Okonkwo, I.A., Anyiam, O.A., Okeugo, C.G., Maduewesi C.O., Okeke, K.K., and Umeadi, I.M (2020). Structural, Stratigraphic and Combination Traps on Outcropping Lithostratigraphic Units of the Anambra Basin, Southeast Nigeria. Petroleum and Coal 62(1):7183

Edegbai, A.J., Emofurieta, W.O (2015). Preliminary assessment of source rock potential and palynofacies analysis of Maastrichtian Dark Shale, SW Anambra basin. Ife J. Sci.17 (1): 131139. 
Edegbai, A.J., Schwark, L., Oboh-Ikuenobe, F.E (2019a). A review of the latest Cenomanian to Maastrichtian geological evolution of Nigeria and its stratigraphic and paleogeographic implications. J. Afr. Earth Sci. 150: 823-837

Edegbai, A.J., Schwark, L., Oboh-Ikuenobe, F.E (2019b). Campano-Maastrichtian paleoenvironment, paleotectonics and sediment provenance of western Anambra basin, Nigeria: multi-proxy evidences from the Mamu Formation. J. Afr. Earth Sci. 156: 203-239

Edegbai, A.J., Schwark, L., Oboh-Ikuenobe, F.E (2020). Nature of dispersed organic matter and paleoxygenation of the Campano-Maastrichtian dark mudstone unit, Benin flank, western Anambra Basin: Implications for Maastrichtian Trans-Saharan seaway paleoceanographic conditions. J. Afr. Earth Sci. 162: 103654

Faboya, O.L., Sonibare, O.O., XU, J.B., Cheng, B., Deng, Q., Wei, Z.W., Olowookere, A., Liao, Z.W (2019). Geochemical characterization of Lower Maastrichtian Mamu Formation kerogens, Anambra Basin, Nigeria. IOP Conf. Series: Earth and Environmental Science 360: 012015.

Gonçalves, P.A., da Silva, T.F., Mendonça Filho, J.G., Flores, D (2015). Palynofacies and source rock potential of Jurassic sequences on the Arruda subbasin (Lusitanian Basin, Portugal). Marine and Petroleum Geology 59:575-592.

Maju-Oyovwikowhe, G.E, Malomi, B.P. (2019). Evaluation of Hydrocarbon Potential, Quality of Source Rock Facies, and Delineating of their Depositional Environment in Mamu Formation of Anambra Basin, Nigeria. J. Appl. Sci. Environ. Manage. 23 (3):383-388

Mendonça Filho, J.G.M., Menezes, T.R., Mendonça, J.O., Oliveira, A.D., Silva, T.F., Rondon, N. F., and Silva, F.S (2012). Organic Facies: Palynofacies and Organic Geochemistry Approaches, Geochemistry - Earth's System Processes, Dr. Dionisios Panagiotaras (Ed.), ISBN: 978-953-51-0586-2, In. Tech.

Meyers, P.A (1994). Preservation of elemental and isotopic source identification of sedimentary organic matter. Chem. Geol. 114, 289-302

Nigerian Geological Survey Agency (2006). Geological and Mineral Resources Map of Edo State.
Obi, G.C., and Okogbue, C.O (2004). Sedimentary response to tectonism in the CampanianMaastrichtian succession, Anambra Basin, Southeastern Nigeria: J. Afr. Earth Sci. 38, 99108

Ogbamikhumi, A., Igbinigie, N.S., Aiworo, O.E (2017). Organic Geochemical Evaluation for Source Rock Potentials of Mamu Formation Exposed at The Benin Flank of Anambra Basin. Indo-Iranian J. Sci. Res. 1: 41-45

Ogala, J. E (2011). Hydrocarbon potentials of The Upper Cretaceous coal and shale units in the Anambra Basin, Southeastern Nigeria. Petroleum and Coal, 53(1): $35-44$

Olatinpo, O.A., Akande, S.O., Taiwo, O.B. Faseki, O.E (2016). Hydrocarbon Generation Potential and Thermal Maturity of some Coal and Shale of Okobo Area, Mamu Formation, Southern Nigeria. Inter. Basic Appl. Res. J. 2 (7): 31-46

Omatshola, E (2019). Why the Cretaceous. In: Ejedawe, J.E (Eds), Cretaceous basins in Nigeria Workshop, Abuja (May 6 and 7, 2019), p.9-14

Pearson, D.L (1984). Pollen/Spore Colour 'Standard': Version 2. Phillips Petroleum Company, geology branch, privately distributed

Peters, K.E., and Cassa, M.R (1994). Applied source rock geochemistry, in Magoon, L.B., and Dow, W.G., eds., The petroleum system-From source to trap: Tulsa, Okla., Am. Assoc. Petro. Geologists Memoir 60: 93-117

Thakur, O.P., and Dogra, N.N (2011). Palynofacies characterization for hydrocarbon source rock evaluation in the Subathu Formation of Marhighat, Sirmaur district, Himachal Pradesh. $J$. Earth Syst. Sci. 120 (5): 933-938

Troudi H., Rezouga N., Meskini A (2012). The Unconventional Gas Play in Tunisia Ghadames Basin Require a Certain Edge: Shale Gas Workshop - Oran, Algeria 27-29 February

Tyson, R.V (1995). Sedimentary Organic Matter, Organic facies and palynofacies, Chapman and Hall, London, 615 p 